\title{
THE LEVEL OF PHYSICAL ACTIVITY AND SELECTED SOMATIC INDICATORS IN RELATION TO THE DIET QUALITY OF STUDENTS STUDYING IN FACULTIES IN THE DISCIPLINE OF HEALTH SCIENCES
}

\author{
Robert Gajdal
}

\author{
${ }^{1}$ Wrocław University of Environmental and Life Sciences, Faculty of Biotechnology and Food Sciences, \\ Department of Human Nutrition, 37 Chełmońskiego street, 51-630 Wrocław, Poland
}

\begin{abstract}
Background. Diet and physical activity are very important lifestyle features with an impact on the development and proper functioning of the body.

Objective. The aim of the study was to assess the relationship between the level of physical activity and selected somatic indicators and the diet quality of students studying in the field of Health Sciences.

Material and methods. The studied group consisted of 609 students aged 18-30. The study identified four categories of diet quality indicators based on the index of a healthy diet and the index of an unhealthy diet. These indicators were subjected to statistical analysis in relation to the level of physical activity determined by the International Physical Activity Questionnaire (IPAQ) method and selected somatic features of the subjects: Body Mass Index (BMI), Waist-Hip Ratio (WHtR) and Waist Circumstance (WC).

Results. A high level of physical activity statistically significantly differentiated the categories of diet quality indicators. A larger percentage of respondents with a high level of physical activity had an indicator with the best health features of diet characteristics among all diet quality indicators selected in the study. Also, obesity according to the BMI and abdominal obesity with a high risk of metabolic complications according to the WC index statistically significantly differentiated the categories of diet quality indicators. A larger percentage of obese subjects according to BMI and WC, characterized the indicator about the worst health features of diet among all diet quality indicators selected in the study.

Conclusions. Education programs related to healthy eating should be implemented among students of Health Sciences, especially those who are overweight or obese.
\end{abstract}

Key words: diet quality, physical activity, somatic indicators, BMI, WC, WHtR, students, youth

\section{STRESZCZENIE}

Wprowadzenie. Sposób żywienia i aktywność fizyczna stanowią bardzo ważne elementy stylu życia mające wpływ na rozwój i prawidłowe funkcjonowanie organizmu.

Cel. Celem badań była ocena zależności między poziomem aktywności fizycznej i wybranymi somatycznymi wskaźnikami stanu ożywienia a dietą studentów kształcących się na kierunkach w dyscyplinie Nauk o Zdrowiu.

Material i metody. W badaniu wyłoniono 4 kategorie wskaźników jakości diety opartych na indeksie diety sprzyjającej zdrowiu i indeksie diety nie sprzyjającej zdrowiu. Wskaźniki te poddano opracowaniu statystycznemu w odniesieniu do poziomu aktywności fizycznej określonego metodą IPAQ oraz wybranych badanych cech somatycznych: BMI, WHtR i WC.

Wyniki. Wysoki poziom aktywności fizycznej istotnie statystycznie różnicował kategorie wskaźników jakości diety. Największy odsetek badanych, o wysokim poziomie aktywności fizycznej, charakteryzował wskaźnik o najlepszych cechami zdrowotnymi diety spośród wszystkich wyłonionych w badaniu kategorii wskaźników jakości diety. Również otyłość według wskaźnika BMI oraz otyłość brzuszna z wysokim ryzykiem powikłań metabolicznych według wskaźnika WC statystycznie istotnie różnicowały kategorie wskaźników jakości diety. Największy odsetek badanych z otyłością, według BMI i WC, charakteryzował wskaźnik o najgorszych cechach zdrowotnych diety spośród wszystkich wyłonionych w badaniu kategorii wskaźników jakości diety.

Wnioski. Wśród studentów kierunków Nauk o Zdrowiu, szczególnie z nadwagą lub otyłością, należy wdrożyć programy edukacji związane z prozdrowotnym sposobem żywienia.

Słowa kluczowe: jakość diety, aktywność fizyczna, wskaźniki somatyczne, BMI, WC, WHtR, studenci, młodzież

Corresponding author: Robert Gajda, Uniwersytet Przyrodniczy we Wrocławiu, Wydział Biotechnologii i Nauk o Żywności, Katedra Żywienia Człowieka, ul. Chełmońskiego 37, 51-630 Wrocław, Tel. +48 71 3207758, Mobile phone: 507120428; e-mail: robert.gajda@upwr.edu.pl 


\section{INTRODUCTION}

The way people are fed is determined by many factors, especially economic, individual and environmental ones $[14,15,26]$. Physical activity is among the individual determinants differentiating the way people are fed $[11,27]$. Diet and physical activity are very important lifestyle elements affecting the development and proper functioning of the body and more complete use of the physical and mental capabilities of the body [20].

The concept of diet quality has recently gained much attentioninnutritionresearch.Despiteits widespreaduse, the concept of diet quality is poorly defined and difficult to measure. So far, no consensus has been established on how to universally define diet quality and develop a standard indicator of diet quality assessment [1].

A lot of research has been done on methods for assessing diet quality using scenarios identifying healthy dietary patterns [6]. Among them, we distinguish the following diet quality indicators: HEI (Healthy Eating Index), AHEI-2010 (Alternative Healthy Eating Index2010), HDI (Healthy Diet Index), DQI (Diet Quality Index), and AMED (Alternative Mediterranean Diet score). In the global literature, there is a relationship between these indicators and the level of physical activity [7] and/or somatic indicators, e.g. BMI (Body Mass Index), WC (Waist Circumference) and WHR (WaistHip Ratio) [25]. Unfortunately, in many countries, a change in dietary patterns, especially in children and adolescents, associated with increased consumption of sweetened non-alcoholic beverages, sweets, potato chips and processed or unprocessed red meat, as well as reduced consumption of vegetables and fruits, whole grains, low-fat dairy products and nuts, is associated with an increase in obesity $[19,21]$, concomitant with a change in the body's somatic features. In addition, in the study of "unhealthy" dietary patterns (the so-called Western diet), the combination of these patterns with a low level of physical activity is seen $[23,30]$.

The aim of the study was to assess the diet quality of students studying in the discipline of Health Sciences in relation to their level of physical activity and somatic indicators.

\section{MATERAL AND METHODS}

This empirical study was carried out between October and December 2018 among full-time students. The studied population group consisted of 609 respondents aged 19-30. Students represented two universities. The surveyed students were educated in six fields in the discipline of Health Sciences, i.e. cosmetology - 233 people, dietetics - 165 people, physiotherapy - 96 people, emergency medical services -57 people, nursing - 49 people and electroradiology -9 people. The detailed characteristics of the studied population group in terms of the level of physical activity and selected somatic indicators, taking into account the sex and age of the subjects, are presented in Table 1.

Table 1. Characteristics of the studied population group [\%]

\begin{tabular}{|c|c|c|c|c|c|c|c|}
\hline \multirow{2}{*}{$\begin{array}{l}\text { Features of the } \\
\text { population group }\end{array}$} & \multirow{2}{*}{$\begin{array}{r}\text { Generally } \\
(\mathrm{N}=609)\end{array}$} & \multicolumn{2}{|c|}{ Gender } & \multicolumn{4}{|c|}{ Age in years } \\
\hline & & $\begin{array}{c}\text { men } \\
(\mathrm{N}=106)\end{array}$ & $\begin{array}{l}\text { women } \\
(\mathrm{N}=503)\end{array}$ & $\begin{array}{c}19-21 \\
(\mathrm{~N}=430)\end{array}$ & $\begin{array}{c}22-24 \\
(\mathrm{~N}=128)\end{array}$ & $\begin{array}{c}25-27 \\
(\mathrm{~N}=35)\end{array}$ & $\begin{array}{c}28-30 \\
(\mathrm{~N}=17) \\
\end{array}$ \\
\hline Generally & 100.0 & 17.4 & 82.6 & 70.6 & 21.0 & 5.7 & 2.7 \\
\hline \multicolumn{8}{|l|}{ Level of physical activity } \\
\hline moderate & 24.7 & 16.0 & 26.4 & 23.5 & 28.3 & 20.0 & 42.9 \\
\hline $\operatorname{high}^{\text {P. W }}$ & 75.3 & 84.0 & 73.6 & 76.5 & 71.7 & 80.0 & 57.1 \\
\hline \multicolumn{8}{|c|}{ Selected somatic indicators } \\
\hline \multicolumn{8}{|l|}{ BMI } \\
\hline underweight & 10.0 & 1.9 & 11.7 & 11.4 & 6.3 & 8.6 & 5.9 \\
\hline norm & 73.8 & 59.4 & 76.9 & 73.7 & 76.4 & 77.1 & 52.9 \\
\hline overweight $^{\mathrm{P} . \mathrm{W}}$ & 13.8 & 33.0 & 9.7 & 13.0 & 12.6 & 14.3 & 41.2 \\
\hline obesity ${ }^{\text {P. W }}$ & 2.4 & 5.7 & 1.6 & 1.9 & 4.7 & 0.0 & 0.0 \\
\hline \multicolumn{8}{|l|}{ WHtR } \\
\hline norm & 79.5 & 65.1 & 82.9 & 82.3 & 72.4 & 77.1 & 64.7 \\
\hline abdominal obesity ${ }^{\mathrm{P}}$ & 20.5 & 34.9 & 17.1 & 17.7 & 27.6 & 22.9 & 35.3 \\
\hline \multicolumn{8}{|l|}{ WC } \\
\hline norm & 78.8 & 75.5 & 79.5 & 81.6 & 70.1 & 80.0 & 70.6 \\
\hline *abdominal obesity with & & & & & & & \\
\hline IR of MC & 14.1 & 17.9 & 13.3 & 12.6 & 18.1 & 17.1 & 17.6 \\
\hline $\begin{array}{r}* * \text { abdominal obesity } \\
\text { with } \mathrm{HR} \text { of } \mathrm{MC}^{\mathrm{W}}\end{array}$ & 7.1 & 6.6 & 7.2 & 5.8 & 11.8 & 2.9 & 11.7 \\
\hline
\end{tabular}

*Abdominal obesity with an increased risk of metabolic complications; ** Abdominal obesity with the high risk of metabolic complications

P. WStatistically significent differences between the feature of the population group and its gender $\left({ }^{\mathrm{P}}\right)$ and its age $\left({ }^{\mathrm{W}}\right)$; level of significant $\mathrm{p} \leq 0.05\left(C h i^{2}\right.$ test $)$ 
The study was conducted by means of a survey. The research sample was selected arbitrarily, i.e. a survey was conducted, and the WC was measured among all students present at the university on the day of the study who agreed to participate in the study. As a result of the study, 609 surveys were collected.

The survey used in the study consisted of two research tools. The first of these was the QEB questionnaire for researching nutritional behaviours and opinions on food and nutrition developed by the Group of Behavioural Nutrition Conditions of the Committee on Science of Human Nutrition PAN. Based on the QEB questionnaire, intake was assessed for 16 groups of food products by using a 6-grade intake frequency scale, where grade 1 meant "never" and grade 6 "several times a day". The second research tool was the shortened version of the IPAQ (International Physical Activity Questionnaire), enabling the collection of information on various forms of physical activity of respondents over the last 7 days. The collected data on weekly physical activity were calculated according to a strictly defined scheme into MET units (Metabolic Equivalent of Task) [12]. On the basis of physical activity expressed in MET units (MET-minutes/week), people with moderate (600-3000 MET-minutes/week) and high levels of physical activity (>3000 MET-minutes/week) were distinguished. None of the subjects had low levels of physical activity ( $<600$ MET-minutes/week). In addition, as part of the survey, respondents were asked to provide body weight in kilograms and body height in centimetres. WC was measured in a standing position using anthropometric tape at the greatest narrowing of the torso at the waist, with the abdominals relaxed.

In the statistical analysis, the number and percentage of students with a given feature were used to describe the population structure. During the statistical analysis, based on the frequency of consumption of 16 groups of food products, two diet quality indicators were distinguished, in accordance with the procedure for the preparation of nutritional data from the QEB questionnaire by Wadolowska and Krusińska, 2014 [29]. The first of the extracted indicators was the "healthy diet index" with the acronym pHDI- 8 , which was calculated by summing the frequency of consumption (fold/ day) of the eight indicated food groups (wholemeal bread, milk, fermented milk drinks, cottage cheese, preparations and dishes from fish, dishes from legumes, fruit and vegetables). The second indicator extracted was the "unhealthy diet index", with the acronym nHDI-8, which was calculated in the same way using the following eight other food groups (fast food, fried foods, pillow cheese, sweets and confectionery, canned, sweetened carbonated drinks, energy drinks, and alcoholic drinks). Indexes were calculated by adding up the intake frequencies, previously expressed as fold/day, and then converted to a 100-point scale. On the basis of this scale, the intensity of dietary traits favourable or un favourable to health was decided, while the intensity of traits was assumed to be low ( $0-25$ points), moderate (26-75 points) or high (76-100 points).

Based on the calculated point values of the "healthy diet index" (pHDI-8) and "unhealthy diet index" (nHDI-8) of all observations, four categories of variables describing the diet quality of respondents were derived, i.e. category 1 - low intensity of pHDI-8 and nHDI- 8 ; category 2 - moderate intensity of pHDI-8 and low intensity of nHDI-8; category 3 - low intensity of pHDI-8 and moderate intensity of nHDI-8; category 4 - moderate intensity of pHDI- 8 and nHDI-8.

When assessing the somatic parameters (body weight, height, WC), basic nutritional assessment indicators were calculated, i.e. BMI, WC, WHtR (waist-to-height ratio). WHO recommendations were adopted as BMI diagnostic criteria for assessing nutritional status [30]. According to these criteria, BMI $<18.5 \mathrm{~kg} / \mathrm{m}^{2}$ indicates underweight, $18.5-24.9 \mathrm{~kg} / \mathrm{m}^{2}$ normal weight, $25.0-29.9$ $\mathrm{kg} / \mathrm{m}^{2}$ overweight, and $\geq 30.0 \mathrm{~kg} / \mathrm{m}^{2}$ obesity. The WHO Report 2008 regarding WC recommendations were adopted as diagnostic criteria assessment of abdominal obesity and the risk of metabolic complications associated with it [22]. According to this report, a WC above $94 \mathrm{~cm}$ for men and $80 \mathrm{~cm}$ for women is associated with abdominal obesity with a significant risk of metabolic complications, and values above 102 centimetres for men and 88 centimetres for women indicate abdominal obesity with a very high risk of metabolic complications. As the WHtR diagnostic criterion for abdominal obesity and an increased risk of heart disease and diabetes, we adopted the cut-off point of 0.5 . A WHtR value $\geq 0.5$ indicates abdominal obesity and these complications $[4,5]$.

The comparison of qualitative features i.e. the BMI, WC and WHtR criteria, and the intensity categories of diet quality indicators, including the evaluation of statistically significant differences, was performed by using the $\mathrm{Chi}^{2}$ test. The significance level was assumed to be 0.05 .

Statistical analysis was performed by using the Statistica Basic 13 PL statistical program.

\section{RESULTS}

Almost $4 / 5$ of the study population group was characterized by low-intensity pHDI- 8 and nHDI- 8 features. At the same time, almost $1 / 5$ of respondents were characterized by moderate-intensity pHDI- 8 features and low-intensity nHDI- 8 features. Only in the case of $2.0 \%$ of academic youth was there lowintensity pHDI- 8 and moderate-intensity nHDI- 8 , according to dietary assessment, and in the case of $0.8 \%$, moderate-intensity pHDI- 8 and nHDI- 8 . None of the examined people were characterized by highintensity pHDI- 8 and nHDI- 8 features (Table 2). 
Table 2. Categories of intensity of features of diet quality indicators of the studied population group. ta king into account its level of physical activity and selected somatic indicators of nutritional status [\%]

\begin{tabular}{|c|c|c|c|c|c|}
\hline \multirow{3}{*}{$\begin{array}{l}\text { Features of the } \\
\text { population group }\end{array}$} & \multirow[t]{3}{*}{ Generally } & \multicolumn{4}{|c|}{ Categories of diet quality indicators } \\
\hline & & category 1 & category 2 & category 3 & category 4 \\
\hline & & $\begin{array}{l}\text { low intensity of } \\
\text { features pHDI- } 8^{*} \\
\text { and nHDI- } 8^{* *}\end{array}$ & $\begin{array}{l}\text { moderate intensity } \\
\text { of features pHDI- } 8 \\
\text { and low intensity of } \\
\text { features nHDI- } 8\end{array}$ & $\begin{array}{l}\text { low intensity of } \\
\text { features pHDI- } 8 \text { and } \\
\text { moderate intensity of } \\
\text { features nHDI- } 8\end{array}$ & $\begin{array}{c}\text { moderate } \\
\text { intensity of } \\
\text { features pHDI-8 } \\
\text { and nHDI-8 }\end{array}$ \\
\hline $\mathrm{N}$ & 609 & 473 & 119 & 12 & 5 \\
\hline Generally & 100 & 77.7 & 19.5 & 2.0 & 0.8 \\
\hline \multicolumn{6}{|l|}{ Physical activity } \\
\hline $\begin{array}{r}\text { Level of physical activity } \\
\text { moderate } \\
\text { high }^{\text {Is }}\end{array}$ & $\begin{array}{l}24.7 \\
75.3\end{array}$ & $\begin{array}{l}25.8 \\
74.2\end{array}$ & $\begin{array}{l}20.0 \\
80.0\end{array}$ & $\begin{array}{l}25.0 \\
75.0\end{array}$ & $\begin{array}{l}20.2 \\
79.8\end{array}$ \\
\hline \multicolumn{6}{|c|}{ Selected somatic indicators of nutritional atatus } \\
\hline $\begin{array}{r}\text { BMI } \\
\text { underweight } \\
\text { norm } \\
\text { overweight } \\
\text { obesity }{ }^{\text {IS }}\end{array}$ & $\begin{array}{l}10.0 \\
73.8 \\
13.8 \\
2.4\end{array}$ & $\begin{array}{l}10.1 \\
73.2 \\
14.2 \\
2.5\end{array}$ & $\begin{array}{c}10.1 \\
74.8 \\
14.3 \\
0.8\end{array}$ & $\begin{array}{c}8.3 \\
74.8 \\
14.3 \\
8.4\end{array}$ & $\begin{array}{c}0.0 \\
100.0 \\
0.0 \\
0.0\end{array}$ \\
\hline $\begin{array}{l}\text { WHtR } \\
\text { norm } \\
* * \text { abdominal obesity }\end{array}$ & $\begin{array}{l}79.5 \\
20.5 \\
\end{array}$ & $\begin{array}{l}79.7 \\
20.3 \\
\end{array}$ & $\begin{array}{l}79.8 \\
20.2 \\
\end{array}$ & $\begin{array}{l}75.0 \\
25.0 \\
\end{array}$ & $\begin{array}{l}60.0 \\
40.0 \\
\end{array}$ \\
\hline $\begin{array}{r}\text { WC norm } \\
* * * * \text { abdominal obesity } \\
\text { with IR of MC } \\
* * * * * \text { abdominal obesity } \\
\text { with HR of MC IS }\end{array}$ & 14.1 & $\begin{array}{l}12.9 \\
7.2\end{array}$ & $\begin{array}{l}17.6 \\
6.8\end{array}$ & $\begin{array}{l}8.4 \\
8.3\end{array}$ & $\begin{array}{l}40.0 \\
60.0 \\
0.0\end{array}$ \\
\hline
\end{tabular}

*pHDI-8 - „Index of health diet”; **nHDI-8 - „Index of non-healthy diet”; ***Abdominal obesity with an increased risk of heart disease and diabetes; $* * * *$ Abdominal obesity with an increased risk of metabolic complications; ***** Abdominal obesity with the high risk of metabolic complications; ${ }^{\text {Is }}$ Statistical significent differences between the feature of the population group and the categories of intensity of the features of diet quality indicators $\left(C h i^{2}\right.$ test. $\left.\mathrm{p} \leq 0.01\right)$

Slightly less than $1 / 4$ of the respondents were characterized by moderate and over $3 / 4$ by high levels of physical activity. Studying the relationship between the intensity of diet quality traits and the level of physical activity, it was demonstrated that this high level of activity statistically significantly differentiated the percentage of people belonging to individual categories of intensity of diet quality indicators. It was demonstrated that a statistically significantly higher percentage of respondents with a high level of physical activity was characterized by an indicator with a moderate intensity of pHDI- 8 and a low intensity of nHDI- 8 than the percentage of respondents belonging to other categories of diet quality indicators (Table 2).

A comparative analysis of the BMI, WC and WHtR criteria showed that approximately $3 / 4$ of respondents had somatic values characteristic of body weight due. Overweight and obesity were present $16 \%$ of the surveyed population according to the BMI criteria. Of those surveyed, $10 \%$ were underweight according to the criteria of the same indicator. Over $1 / 5$ of respondents were characterized by abdominal obesity according to the criteria of the WC and WHtR index (Table 2). Statistically significant differences were shown only when the relationship between obesity according to BMI criteria and abdominal obesity with a high risk of metabolic complications according to WC and the intensity of diet quality indicators was examined. It was shown that a higher percentage of those who were obese according to the BMI criteria and had abdominal obesity with a high risk of metabolic complications according to the WC criteria were also characterized by a low intensity of pHDI- 8 and a moderate intensity of nHDI- 8 than the percentage of respondents characterized by other categories of diet quality indicators (Table 2).

\section{DISCUSSION}

The results of a study by Dabrowska-Galas et al. [8], regarding the level of physical activity of students of the Medical University of Silesia, reported that depending on the field of study, $0-26 \%$ of respondents had low levels of physical activity, $52 \%-86 \%$ of respondents had moderate levels of physical activity and $8 \%-46 \%$ of respondents had high levels of physical activity. A large share of respondents in the present study with a high level of physical activity and 
the lack of respondents with low levels of physical activity could have resulted from a large participation in the study of persons declaring performing professional activity in addition to academic activity. Angyán et al. [3] pointed out that medical students were characterized by low levels of physical activity due to the burden of academic activity and limited free time. However, Frank et al. [9] reported that American medical students had higher levels of physical activity than their peers.

Overweight and obesity is a global problem, in particular concerning the countries of North America, southwest Europe and Great Britain. This phenomenon applies to all social groups [13]. A low level of physical activity is a factor determining overweight and obesity [13], with these metabolic disorders usually being multifactorial, and a decrease in the level of physical activity is positively correlated with the deterioration of diet quality, aggravating this type of metabolic disorder. For example, the analysis of two observational cohort studies on diet quality indicators, i.e. AHEI and AMED, showed that those respondents who adhered to these indicators more had a higher level of physical activity than those who adhered less to these indicators [7]. Also, in the present study, it was observed that a statistically significantly larger percentage of respondents with a high level of physical activity had an indicator with the best dietary health features among all categories of diet quality indicators selected in the study.

In our study, $16.2 \%$ of the student population was characterized as overweight or obese according to the BMI criteria. Similarly, according to another Polish study conducted by Likus et al. [16], overweight and obesity was present in $13.4 \%$ of students. In addition to obesity, another equally important problem for young people is underweight, which affected up to $10 \%$ of respondents in this study and $9.6 \%$ of students in medicine and health sciences in Likus et al. study [16]. At the same time, it should be pointed out that, although the study showed a relationship between the selected categories of diet quality indicators and overweight and obesity according to the BMI index and abdominal obesity with a high risk of metabolic complications according to the WC index, no statistically significant differentiation between these categories of quality indicators was demonstrated between diet and underweight, body mass norm and overweight according to BMI, body mass norm according to $\mathrm{WC}$ and WHtR, but also abdominal obesity with an increased risk of metabolic complications according to WC.

In our study, the highest percentage of respondents with obesity according to the BMI criteria and abdominal obesity with a high risk of metabolic complications according to the WC criteria was characterized by the indicator with the worst diet health characteristics among all diet quality indicators selected in the study. In turn, several studies found a significant relationship between compliance with healthy diet quality indicators, weight loss and abdominal obesity [28]. Especially often, such a relationship is observed between AMED-type indicators and somatic indicators [25]. Most crosssectional studies report a strong negative correlation between adherence to the Mediterranean diet and the occurrence of obesity, and this has been confirmed by cohort studies [25]. From analysis 2, observational cohort studies on quality indicators for AHEI and AMED diets showed that those subjects who followed these indicators more often had lower BMIs than those who did not (7). In turn, research from Sahrai et al. published in 2019 showed that compliance with healthy AMED diet quality indicators statistically significantly corresponded to lower WC and WHR indicators but did not correspond to the BMI indicator [25]. Such observations are also confirmed by the EPIK-PANACEA study [24]. The results of intervention dietary studies showed that adherence to the Mediterranean diet was associated with a lower BMI and significantly lower abdominal obesity $[2,10$, 17]. In the study by Sahrai et al. [25], there was no significant relationship between the quality indicators of diet type HEI or DQI and the somatic indicators WC, WHR and BMI. Regarding HEI indicators, Mexican Americans also showed no relationship between HEI and $\mathrm{WC}$ in women, but the results were significant in men [25]. A recent study showed that DQI compliance was associated with a decrease in WC and BMI in men, while no relationship was found in women [18]. These gender differences can be explained by the different fat deposits in men and women. Women have a tendency to store fat around the hips and lower limbs, while men tend to accumulate fat in the abdominal area [31].

The main limitation of the study was its nature (cross-sectional studies) and survey method. In addition, the study showed an exceptionally high share of respondents with a high level of physical activity and a lack of respondents with a low level of physical activity in relation to data on the level of student activity in Poland [8]. Most of the students of the surveyed universities declared that they did work outside of academic activity, which had an impact on the results of the assessment of the studied levels of physical activity and which could significantly underestimate the relationship between the studied categories of diet quality indicators and the somatic indicators of the respondents. However, the international standardized IPAQ questionnaire was used in the study. It is the most frequently recommended tool for measuring the level of physical activity [12]. The research sample was selected arbitrarily and included all students 
of two universities present on the day of the study. Furthermore, only the WC indicator was measured. The body weight and height of respondents were recorded in the study based on the values declared by students, which could further reduce the reliability of BMI and WHtR indicators.

\section{CONCLUSIONS}

Nutrition education program should be implemented among students studying in the field of health sciencees, especially those who are overweight or obese and have a low physical activity.

\section{Conflict of interest}

The author declares no conflict of intrest.

\section{REFERENCES}

1. Alkerwi A.: Diet quality koncept. Nutrition $2014 ; 30: 613$ doi: 10.1016/j.nut.2013.10.001.

2. Andreoli A., Lauro S., Di Daniele N., Sorge R., Celi M., Volpe S.L.: Effect of a moderately hypoenergetic Mediterranean diet and exercise program on body cell mass and cardiovascular risk factors in obese women. Eur J Clin Nutr 2008;62:892-897.

3. Angyán L., Téczely T., Mezey B., Lelovics Z.: Selected physical characteristics of medical students. Med Educ 2003;8:1 doi: 10,3402/meo.v8i.4328.

4. Ashwell M., Hsieh S.D.: Six reasons why the waistto-height ratio is a rapid and effective global indicator for health risks of obesity and how its use could simplify the international public health message on obesity. Int J Food Sci Nutr 2005;56(5):303 doi: 10.1080/09637480500195066.

5. Browning L.M., Hsieh S.D., Ashwell M.: A systematic review of waist-to-height ratio as a screening tool for the prediction of cardiovascular disease and diabetes: 0,5 could be a suitable global boundary value. Nutr Res Rev 2010;23(2):247 doi: 10.1017/S0954422410000144.

6. Coulston A.M.: The search continues for a tool to evaluate dietary quality. Am J Clin Nutr 2001;74:417 doi: 10.1093/ajen/74.4.417.

7. Ding M., Ellervik Ch., Huang T., Jensen M.K., Curhan G.C., Pasquale L.R., Kang H., Wiggs J.L., Hunter D.J., Willett W.C., Rimm E.B., Kraft P., Chasman D.I., Qi L., $H u$ F.B., Qi Q.: Diet Quality and genetic association with body mass index: results from 3 observational studies. Am J Clin Nutr 2018;108:1291 doi: 10.1093/ ajen/ngy203.

8. Dąbrowska-Galas M., Plinta R., Dąbrowska J., Skrzypulec-Plinta $V$ : Physical activity in students of the Medical University of Silesia in Poland. Phys Ther 2013;93(3):384 doi: 10.2522/ptj.20120065 (in Polish).

9. Frank E., Tong E., Lobelo F., Carrera J., Duperly J.: Physical activity levels and counseling practices of US medical students. Med Sci Sports Exerc 2008;40:413 doi: $10.1249 / \mathrm{mss} .0 \mathrm{~b} 013 \mathrm{e} 31815 \mathrm{ff} 399$.
10. Goulet J., Lamarche B., Nadeau G., Lemieux S. Effect of a nutritional intervention promoting the Mediterranean food pattern on plasma lipids, lipoproteins and body weight in healthy FrenchCanadian women. Atherosclerosis 2003;170:115 doi: 10.1079/BJN20041198.

11. Gronowska-Senger A.: Zarys oceny żywienia [Qutline of nutrition assessment]. Warszawa, Wydawnictwo SGGW, 2013 (in Polish)

12. International Physical Activity Questionnaire - IPAQ Portal. Available http://www.ipaq.ki.se. (Accessed 2.01.2017).

13. Janssen I., Katzmarzyk P.T., Boyce W.F., Vereecken C., Mulvihill C., Roberts C., Currie C., Pickett W.: Comparison of overweight and obesity prevalence in school-aged youth from 34 countries and their relationship with physical activity and dietary patterns. Obes Rev 2005;6:123 doi: 10.1111/j.1467789X.2005.00176.x.

14. Jeżewska-Zychowicz M.: Zachowania żywieniowe i ich uwarunkowania. Wydanie 2 [Nutritional behaviors and their determinants. Edition 2]. Warszawa, Wydawnictwo SGGW, 2007 (in Polish).

15. Lallukka T., Laaksonen M., Rahkonen O., Roos E., Lahelma E.: Multiple socio-economic circumstances and healthy food habits. Eur J Clin Nutr 2007;61:701 doi: 10.1038/sj.ejen.1602583.

16. Likus W., Milka D., Bajor G., Jachowicz-Łopata M., Dorzak B.: Dietary habits and physical activity in students from the medical university of Silesia in Poland. Rocz Panstw Zakl Hig 2013;64(4):317-324. (PMID: 24693717)

17. Martinez-Gonzalez M.A., Garcia-Arellano A., Toledo E., Salas-Salvado J., Buil-Cosiales P., Corella D., Covas M.I., Schroder H., Aros F., Gomez-Gracia E., Fiol M., Ruiz-Gutiérrez V., Laperta J., Lamuela-Raventos R.M., Serra-Majem L., Pinto X., Muñoz M.A., Wärnberg J., Ros E., Estruch R.: A 14-item Mediterranean diet assessment tool and obesity indexes among highrisk subjects: The PREDIMED trial. PLOS ONE 2012;7(8):e43134 doi: 10.1371/journal.pone.0043134.

18. Mertens E., Deforche B., Mullie P., Lefevre J., Charlier R., Knaeps S., Huybrechts I., Clarys P.: Longitudinal study on the association between three dietary indices, anthropometric parameters and blood lipids. Nutr Metab 2015;12:47 doi: 10.1186/s12986-015-0042-1.

19. Mozaffarian D., Hao T., Rimm E.B., Willett W.C., Hu F.B.: Changes in diet and lifestyle and long-term weight gain in women and men. N Engl J Med 2011;364:2392 doi: 10.1056/NEJMao1014296.

20. Pilch W., Janiszewska R., Makuch R., Mucha D., Pałka $T$ : Racjonalne odżywianie i jego wpływ na zdrowie [Rational nutrition and its impast on health]. Hyg Pub Health 2011;46(2):244-248.

21. Report of Joint WHO/FAO Experts Consultation on Diet, Nutrition and the of Chronic Disease. Technical Report Series 916, Geneva 2003.

22. Report ofaWHOExpertConsultation. Waist circumference and Waist-Hip Ratio: Genewa 2008. Available https:// www.cdc.gov/nchs/data/nhanes/nhanes_07_08/manual_ an.pdf. 
23. Robinson T.N.: Reducing children's television viewing to prevent obesity: a randomized controlled trial. JAMA 1999;282:1561-1567.

24. Romaguera D., Norat T., Vergnaud A.C., Mouw T., May A.M., Agudo A., Buckland G., Slimani N., Rinaldi S., Couto E., et al.: Mediterranean dietary patterns and prospective weight change in participants of the EPICPANACEA project. Am J Clin Nutr 2010;92:912 doi: 10.3945/ajcn.2010.29482.

25. Sahrai M.S., Huybrechts I., Biessy C., Gunter M.J., Romieu I., Rorres-Mejia G., Dossus L.: Association of a priori-defined dietary patterns with anthropometric measurements: A Cross-Sectional Study in Mexican Women. Nutrients 2019;11:603 doi: 10,3390/ nu11030603.

26. Schur E., Noonan C., Polivy J., Goldberg J., Buchwald $D .:$ Genetic and environmental influences on restrained eating behavior. Int J Eat Disord 2009;42(8)765 doi: 10.1002/eat.20734.

27. Sowa I.: Determinanty a racjonalność zachowań konsumpcyjnych dzieci i młodzieży [Determinants and rationality of consumer behavior of children and youth]. Katowice. Wydawnictwo Akademii Ekonomicznej w Katowicach, 2005 (in Polish).
28. Stoody E.E., Spahn J.M., McGrane M.M., MacNeil P.C., Fungwe T.V., Altman J.M., Lyon J., Obbagy J.E., Wong Y.P.: A Series of Systematic Reviews on the Relationship between Dietary Patterns and Health Outcomes; United States Department of Agriculture: Alexandria, VA, USA, 2014:501.

29. Wądołowska L., Krusińska B.: Procedura opracowania danych żywieniowych $\mathrm{z}$ kwestionariusza QEB [Procedure for prepering nutrition data from the QEB questionnaire]. Available https://www.researchgate. net/publication/271653184_ Procedura_opracowania danych_zywieniowych_z_kwestionariusza_QEB (Accessed 17.01,2019) (in Polish).

30. WHO. Body Mass Index - BMI Portal. Available www. euro.who.int/en/health-topics/disease-prevention/ nutrition/a-healthy-lifestyle/body-mass-index-bmi (Accessed 16.01.2019).

31. Yoshida Y., Scribner R., Chen L., Broyles S., Phillippi S., Tseng T.S.: Diet quality and its relationship with central obesity among Mexican Americans: Findings from National Health and Nutrition Examination Survey (NHANES) 1999-2012. Pub Health Nutr 2017;20:1193 doi: $10.1017 / \mathrm{S} 1368980016003190$.

Received: 08.01.2020

Accepted: 28.02.2020 